\title{
Miniature dissonance and the museum space: Reconsidering communication through miniaturisation
}

J. Davy

There are millions of decontextualized objects from diverse societies in classically designed museums, spaces largely developed and structured along Enlightenment academic principles. These institutions, as a core function, seriate the material culture of the peoples of the world and re-present it in consumable packages to a broad audience. As institutions, they were often deliberately conceived as venues of "scientific" propaganda by which European dominion over other peoples of the world could be justified and promulgated (e.g. Errington, 1998; Davies 2000; Brown 2009). Efforts to decolonise museums, to recognise their harmful histories and develop a more ethical approach to curation are ongoing; they operate in conjunction with social movements which recognise that imposed legal and political systems are often weighted against colonised peoples and seek to redress this balance by acknowledging that the systems in place are fundamentally flawed, based on historical mutual misapprehensions of custom, law, economy and tradition (e.g. Pearce 1992; Sola 1997; Clerici 2002; Geismar 2013).

One of the most significant theoretical constructs to have contributed to this movement is the concept of the contact zone. First posited by Mary Louise Pratt, a contact zone occurs when there is a clash or collaboration between distinct cultures struggling with 'asymmetrical relations of power' (1991, 34). The term was adapted explicitly for the museum space by James Clifford, and has led to a paradigmatic shift in the ways in which museums collaborate with indigenous viewpoints (Boast 2011). Clifford's examples were with Native American communities from the Northwest Coast, and he found that for community members visiting the museum space 'the collected objects are not primarily "art", but rather 'aide-mémoires, occasions for the telling of stories and the singing of songs' (Clifford, 1999 [1997], 435-437).

This has at times been considered a 'site of conflict' (Brown 2009, 145), in which indigenous priorities confront curatorial preoccupations in which 'collections ... are for research or they are surely for nothing' (Keene 2005, 45), conditions in which noncurators can often feel overwhelmed; Haida artist Robert Davidson once recalled that When I first came to Vancouver, I met an incredible barrage of anthropologists. I regarded them as people who held the knowledge, and so I was afraid to say anything in front of them for fear of saying the wrong thing. I was intimidated' (Harris, 1992 [1966], 
XIII). In this situation, 'source community members are wary of contributing to museum-led consultation exercises which do not lead to change within museums or benefits to their people' (Peers \& Brown 2003, 2)

As power relations have been addressed in these contact zones over recent years, they have tilted away from the needs of the institution and towards those of the indigenous participants. Institutional research has thus become a secondary consideration, superseded by decidedly non-Enlightenment environments of communicative and emotional engagement, in which Native visitors now 'expected to generate knowledge for themselves, knowledge that would be put into practice in various ways in their community' (Krmpotich \& Peers 2013, 35). Haida curator Nika Collision considers this the central purpose of such collections, noting of them that 'I like to think [historic Haida artists] put a string on their work, binding us to something that is so much more than art. Binding us so that we'd come together in the future, when the time was right.' (Collison 2016). To Collison these objects are not mere icons of the historical material culture of her people, but inter-generational signposts, laden with ideological communication.

This article explores the contested contact zone of the museum space and the historical misapprehensions and omission which occur when artificial categorisation is imposed upon objects. It will do so by considering engagement with a body of material with a particular feature which makes these objects greater bearers of ideological freight than the mundane items of the everyday. Objects weighted with meaning as part of their very conception, objects without mechanical use; miniatures from the Northwest Coast of North America. Miniatures as a class, and from this area in particular, have been consistently misunderstood by museums, and this article will explain why this has been the case and the implications for both participants in the museum contact zone.

\section{Miniaturisation and museum seriation}

There are a number of recent studies which have considered theoretical approaches to the cognitive and mechanical processes by which miniature objects have been created (e.g. Phillips 1998; Mack 2007; Evans 2012; Knappett 2012; Foxhall 2014). These indicate a growing acceptance in material culture studies that miniature objects are a distinct and troublesome object typology, not always easy for scholars to describe or seriate. It has been noticed that they 'epitomize, echo and reverberate meaning captured in and associated with 
other objects, while creating new meanings of their own' (Foxhall 2014, 1), through 'certain physical and semiotic properties ... that enable them to bear meaning in an intensified fashion, while paradoxically being physically remote from those forms of which they are iconic or indexical' (Knappett 2012, 103).

My own recent research holds that these physical properties, or 'affordances', can be characterised as an 'elemental' system comprised of three qualities, mimesis, simplification and scaling, which in combination create the physical structure of the underlying ideological artefact (Davy 2015). Miniatures bear iconic, mimetic association with another object or thing, a 'prototype', defined here as 'the entity which the index represents visually . . o or non-visually' (Gell 1998, 26), they are then reduced in scale and complexity from this prototype, which does not need a physical presence; neither does the miniature have an absolute maximum or minimum size: the Sistine Chapel is after all a miniature of the end of the world (Lévi-Strauss 1966 [1962], 23).

It is examination of these affordances that enable scholars to consider miniatures not as simple representations of their larger prototypes, but as expressions of ideology; a means for transmitting ideological information among diverse audiences in ways that are subtle and can be actively subversive, often creating a safe satirical space for dialogue between colonised and coloniser. In the museum environment however these objects are frequently misunderstood. Their messages can torque under interpretation by curators, twisting in ways not envisaged by the original maker (see Pinney 2005, 268-270). The reasons these objects can torque so dramatically is explicitly rooted in both the manufacture of the object and the curatorial processes of the museum, as the conflicting priorities of the contact zone explicitly remakes these objects of very specific communication into casual indexes of entire peoples.

The first part of this process is caused by the segregation of objects in the museum. Otherwise known as seriation, cataloguing or categorisation, objects are conspicuously separated into distinct overlapping categories; assigned, based on provenance or expert subjective assessment, into an artificial type, material, culture, function and so on. This of course has a practical purpose. Without a means of seriation, museums would be hopelessly unmanageable. Historic museum collections are haphazard; 'not made according to a deliberate plan to tell a specific story. Instead the objects came from explorers, missionaries and traders, then circulated in a secondary market that deprived them of any provenance information obtained by their initial collectors' (King 2012, 57). In this chaotic 
environment, seriation is a perfectly sensible practical technique for managing diverse and unscientifically assembled collections of material culture.

Since the first scientific collectors, museums have divided by category and broad cultural or regional distinctions that make more sense within the curatorial environment than in actual historical or anthropological conditions. These collectors of the early Enlightenment were operating under a specific set of European scientifically-informed criteria; a very different understanding of the world from that we recognise today, and yet the systems used by museums worldwide remain rooted in seriation practices imbued with these outdated assumptions from their very creation.

This system can preserve and freeze a Eurocentric understanding of the ever-changing world to that understood at the time in which the category was established, restricting institutional revaluation. Furthermore, it awards authority over the category, and thus the object, to the curator, and not to the person who created and used that object, with the result that it is the curator's understanding of the object, not that of its originator, which is subsequently presented to the public.

The anthropologist Claude Lévi-Strauss once recounted a story:

about a very noble American woman anthropologist, a princess among her people, who got her $\mathrm{PhD}$ and became curator in a Canadian museum. One of her white colleagues who was studying those marvellous chief's rattles of the North Pacific Coast, beautifully carved and painted with elaborate designs, was puzzled by one specimen. He turned to her and asked: 'How do you read this rattle?' and she answered 'We don't read them, we shake them' (LéviStrauss 1985, 5).

This, as Levi-Strauss goes on to explain, is at essence the great problem museums have in their use and display of objects from other cultures; they keep trying to read things that were never made to be read. Curators often use this mutual misapprehension to tailor the object to their own interests and priorities, rather than clearly acknowledging that they were never made to be displayed and studied in a large buildings in Europe but were instead made to be 'shaken'.

The result is a set of assumptions that leads to a separation of objects based on their position within this specific European paradigm of functionality. As a result, the collections themselves are physically divided, as figure one demonstrates.

Figure One 
Figure one is a label from a box at the British Museum's ethnography store. It says 'North America. N.W.C.' [or Northwest Coast], and lists the contents as 'modern/trade carvings'. This box is full of miniatures, specifically canoes. At a stage in the history of these objects, a curator categorised the Northwest Coast collections into boxes by dividing by presumed regional/tribal origin and then by purpose, with 'modern/trade carvings' separated after being seriated as souvenir items or 'tourist art', a transcultural hybrid form of art production generally criticised as inauthentic and unrealistic (Poulter, 2011), once generally derided as 'ethno-kitsch, which give all commercial, contemporary arts a bad name' (Graburn 1976, 6). They have remained in this box ever since.

These objects were categorised in this way because they were deemed to be souvenirs; inauthentic, hybridised objects of the European/indigenous cultural clash. Rather than reflecting indigenous ideologies, practices and technology, were instead thought to have been made to conform to non-Native tastes and market forces, and catalogued under an assumption that artworks made of non-traditional materials or with non-traditional techniques were inferior to other, supposedly more authentic objects. For instance, George Heye, founder of the National Museum of the American Indian, had the 'Golden Rule' of 'NO TOURIST ART' within his collection (Lenz 2004; [Heye's emphasis]). In some interpretations by anthropologists this origin renders miniatures as fundamentally compromised objects, useless in studying the societies from which they come. A Danish curator once wrote of hybridised miniatures that they 'find their way to museums, just where they ought not to be, as generally, with a few exceptions, they are devoid of all scientific value' (Porsild 1915, 233).

Curators have historically prized objects that could be used to categorise not just collections, but entire peoples, seeking to pin ethnicities down like butterflies in a drawer. This has long been recognised as a problem; the large-scale collecting of Northwest Coast art in the late nineteenth century for example, during a period of conflict and demographic collapse, means erroneously that 'the most traumatic period in Native American history has provided the material basis for what is traditional and what is not' (King 1986, 70). In Native American contexts this process is openly acknowledged as a form of violence (Holm 1986), the squeezing of imaginative, representative objects through etic functionalist seriation within a colonial space.

The implications of the dismissal of the authenticity of hybridised artworks, as curators take objects from indigenous contexts and position them within the non-Native museum space, are serious, as in doing so the curator is remaking the object to best fit their own 
understanding. Historic examples demonstrate how this remaking process built convenient but simplistic and sometimes actively mendacious narratives about non-European peoples through their collated material culture (e.g. Jonaitis 1991; Ames 1992; Phillips 1998, 92); in the case of the Field Museum in Chicago, an entire gallery was devoted to illustrating the differences between fine art (European), high art (Asian) and low art (everyone else), without once considering how or by whom these categories were constructed and used (Errington 1998, 62); and at the American Museum of Natural History the anthropological work of Franz Boas was deliberately altered in the galleries on the orders of the museum trustees to diminish and obscure the role of women in the management of indigenous communities on the Northwest Coast, to better fit contemporary American narratives of proper gender roles. (Jacknis 1985).

These actions, the determination of authenticity, and thereby identity, by etic curators using etic criteria, is a tactic which delegitimises the histories of disadvantaged or colonised peoples (Lyons, 2002:124), with a direct impact on public understandings of hierarchy, intentionality and function within non-European art, a narrative of European supremacy and primacy seeping into general popular consciousness and proving difficult to counteract. In the past it deliberately contributed to a justification of superiority which supposedly entitled representatives of supposedly more advanced civilisations to conquer, appropriate and dismantle those civilisations they deemed inferior (Asad 1991, 314). As a result, socalled "souvenir art" became invisible to normal art-historical scholarship. Or for that matter, anthropological scholarship' (Errington 1998, 62), 'walled off, untouchable according to orthodox curatorial and discursive practices. Rarely exhibited or published, excluded from the canon, they have been shrouded in silence' (Phillips 1995, 100).

The problem is a contemporary one; as recently as April 2017 a prominent British art dealer announced that finally, 'tribal material is seen as modern art', going on to note that 'finely crafted material with aesthetically pleasing shapes can, when mounted in one's home, become conversation pieces at least the equal of contemporary sculptural pieces' (Ryle 2017, 16). The implicit arrogance in this statement precludes any existing value or intelligence within the 'tribal material' itself, as if it were conveniently originally made for sale within the antiques market rather than components of long-standing networks of value and functionality.

The curatorial profession has changed considerably in its understanding of these problems in recent decades, recognising that 'objects do not exist as 'primitive art'. This is a category created for their circulation, exhibition and consumption outside their original habitats' 
(Myers 2006, 267), but I caution here that the process is incomplete, and that there are still entire categories of material culture which seriation processes have obscured. Miniatures in particular can show how this confusion has occurred because they, above all objects, make curators uncomfortable, causing them to be dismissed as inauthentic and 'unscientific'.

\section{Inherently semiophores}

In 1990 Krzystof Pomian developed the notion that museum objects are what he called 'semiophoric'. He described semiophores as 'natural or artificial objects, kept temporarily or permanently out of the economic circuit, afforded special protection in enclosed spaces adapted specifically for that purpose and put on display' i.e. museum objects $(1990,9)$. These are objects which no longer have any practical, mechanical use, and instead have exist solely for audiences to look at; objects so charged with imposed meaning that they reach a condition of fundamental 'uselessness'. Pomian's distinction is really one of practical functionality rather than 'use'; objects remain useful in the museum space, but their purpose has changed. They no longer perform the tasks for which they were originally created; now they act as indexes of much larger cultural, social or technological phenomena, selected because they engage with a curatorial understanding of what is most typical or most fascinating about that phenomena. In this torqueing process they have, he suggests, exchanged a utilitarian functionality for a representational functionality.

Miniatures can make curators uncomfortable because unlike other supposedly more 'authentic' objects, they are already, inherently semiophores - they were always designed to be objects of fascinated observance. As a result it is harder for curators to bend them to their will, to remake them into the categories they desire in order to make them conform to museum displays.

Curators use objects to model the world in the museum space within a format convenient to themselves and their visitors; miniatures, as representative objects, have conflicting voices which can complicate these efforts. It has been said that this is because miniatures follow a semiophoric trajectory in which they cross the 'precise point on the continuum of miniaturization when its primary function becomes representational rather than utilitarian' as they reduce in size (Phillips 1998, 91); that in the process of scaling down a prototype to a miniature the miniature object exchanges functionality. I hypothesise however that this misunderstands the miniaturisation process, and is at the root of what I term 'miniature 
dissonance', the confusion that miniatures can cause, particularly within rigidly catalogued museum environments.

Miniature dissonance occurs because miniatures are skeuomorphic; they adopt the imagery of one object without actually becoming that object; a miniature canoe for example cannot sail anywhere, a miniature house cannot be lived in; instead the maker 'create[s] a functionless space, for which of us can sit down in a miniature library chair to read a book whose print is so tiny that it is unreadable?' (Mack 2007, 206). Miniatures are always meant to be scaled below the point of utilitarian usefulness, this lack of mechanical functionality is an essential affordance of their very conception and thus unlike other objects transitioning into the museum space, they never exchange functionality because their purpose was always representative.

Rather than hold a utilitarian, mechanical function, they are designed to evoke the indexical networks of meaning connected with their larger prototypes, while bearing none of the practical or mechanical requirements of that prototype, instead inhabiting an imaginary, manipulative and unrealistic space. In the museum therefore they do not exchange functionality; they continue doing the same thing for which they were designed, albeit with contextual information which favours etic rather than emic interpretations of the object within the context of a display. In this context they are intended to be the stand-in for an entire nation or European-defined 'culture' area. Unlike mechanical objects, such as an adze or a bow, they are still capable of performing their original representative function in the museum space, and thus they disrupt curatorial intentions because they cannot be made into semiphores. Their original functionality as objects of representation can never be entirely eclipsed or exorcised because it is established by the very affordances which comprise the object, creating the miniature dissonance which makes curators uncomfortable enough to label them as inauthentic and segregate them into separate boxes.

\section{Miniature canoes and the Northwest Coast}

The case studies for examining this phenomenon are drawn from the indigenous peoples of the Northwest Coast of North America, where artists who make miniatures have not only implicitly understood the representative power of miniatures, but also have recognised the phenomenon of miniature dissonance and have used it to their advantage in their negotiations with non-Native peoples. 
Miniatures from this reagion pre-date European contact (1774); a distinct body of highquality miniature objects have been found in the archaeological site of Ozette in Washington state. Dating to c.1560 this collection demonstrates that 'the making of models does not seem to have been solely for the White tourist trade' (Renker \& Gunther 1990, 426). That miniaturisation as a practice is neither hybrid nor inauthentic.

Nonetheless, some museums have continued to imply that miniatures from the region are insufficiently indigenous or worthy of focused consideration; the St. Petersburg Kunstkamera displays say simply of their impressive collection of miniature canoes that these objects 'were originally intended as toys for children; [and] it was only in the late 18th century that the making of model boats turned into a souvenir craft activity aimed at Europeans' (Berezkin 2007, 39), without consideration of any agency or ideology in the creation of these miniature objects beyond their playful or commercial aspects. Instead, they become facile and inauthentic expressions of acculturated tourist art, not a specific and deliberate mode of cross-cultural communication.

In the three case studies which follow, I will use Northwest Coast miniature canoes as exemplar of ideological communication to contend that facile or inauthentic interpretations of miniature material culture are a mistake. I will show that that Native American artists are and historically have been sophisticated enough not only to prevent European interference from distracting from an object's authenticity, but that they use the deceptive nature of authenticity itself as a cover for satirical and subversive activities through miniaturised art production. In doing so I will demonstrate that not only is the modern movement towards Native agency in the contact zone supported by the objects, but that it always has been.

In 1791 the Spanish expedition of Alessandro Malaspina obtained a small collection of miniature canoes. It has been suggested that these objects were collected in part because the full-sized canoes were too big to travel, and the miniatures commissioned as 'ethnographically representative scientific artefacts', drawing on existing traditions of miniature-making to create collections of 'models' (Glass 2010,181-182). This is where the earlier admonition that these objects have no 'scientific value' becomes significant; if the miniatures were commissioned, and gained their value through this transaction, curators may question to what degree miniatures can be considered authentic expressions of Native American ideology rather than the desires of an Enlightenment navigator. For some, the very presence of European intentionality somehow taints the object, shifting it into different boxes from things known to be 'authentic'.

Figure Two 
The example in Figure two is on display at the Náprstek Museum in Prague, and its proportions are, to a scientific eye, wildly inaccurate. The bow and stern are too big, the midsection narrow and truncated. The knots in the yellow cedar give the hull a misshapen appearance, quite unlike the smooth lines of a full-sized canoe. The hull curves upwards in a sinuous twist that evokes the killer whale depicted in well-executed black Northwest Coast formline design on the exterior. A general lack of proportionality is well-known as a feature of Northwest Coast miniature canoes (Holm 1983, 92), but there has been little consideration of this extreme simplification of the canoe form has significance as a deliberate design element.

Canoes of this type are known as Head canoes after the heavy square bow which features the head of the killer whale crest, and were the highest-quality chiefly canoe of the contact era Northern coast in use among the Tlingit, Tsimshian, Haida and Northern

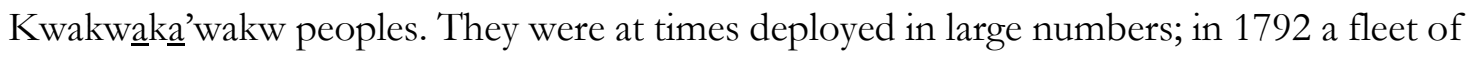
17 head canoes inconclusively battled with the American whaler Columbia in Beaver Harbour (Holm 1987), but are believed to have been relatively rare as a design as they were generally unseaworthy in heavy weather. One prominent Haida canoe carver dismisses them as semi-mythical ceremonial vessels too unwieldy in any kind of wind to have made practical ocean-going canoes (Ramsey \& Jones 2010, 13).

This is therefore an icon not of a 'generic' canoe, but of a ceremonial war canoe of a specific chieftain, a man of considerable military and economic power. Furthermore, a survey of early depictions of life on the Northwest Coast contains many head canoes, few of which have designs remotely resembling those which appear on this miniature (Holm 1987). The lack of decoration in early drawings of these vessels implies that these canoes probably only bore these designs at particular times, such as those of important ceremony; Native depictions of head canoes in other media, such as painted onto feast bowls for example, do show formline decoration. The exaggeration is likely in consequence of this situation; by truncating the mid-section, the crest designs on the bow and stern are given increased prominence and significance to an observer. For the miniature, it is the crest signature and the ceremonial association which is the most important visual element of the miniature.

This being the case, it becomes clear that this miniature is not a scientific model or an icon of head canoes as a class, but an unrealistic, non-proportional, imaginative display of a specific canoe at a specific time. A canoe moreover, associated with a particular chieftain, identified by the crest designs on the sides, at the very height of their ceremonial and temporal authority. Miniatures such as this have long been displayed in the museum space 
as typical examples of Northwest Coast maritime culture, when in fact they are anything but. This is an exceptional, exaggerated and powerful icon of the power of a certain chief, a synecdoche, or index in miniature, of the chieftain who presumably presented it to Malaspina, a man engaged in extended trade negotiations with his visitors. The stakes were high; those groups with ready access to trading ports made a fortune acting as middlemen between European traders and the more distant tribes who could supply otter furs from their hunting territories (Zilberstein 2007).

This miniature is inherently semiophoric; not made to be sailed or even played with, but to be looked at. Presented with tactile miniatures depicting chiefly war canoes resembling killer whales, holding, playing and gazing at them, these strange Europeans, obsessed with otter furs, could find themselves empathising with their Native trading partners, never realising that they were being subtly manipulated to associate the canoe, and thereby all canoes, the waters on which they travelled and the valuable otters which swam in those waters, with the power of certain chieftains, who were in turn associated with the killer whale, the most deadly predator in the region. This miniature is therefore not a simple reconstruction of a canoe, but an embodiment of the power of suggestion at the very cutting edge of the contact zone.

Figure three

The second case study appears nearly a century later, when miniature head canoes were still being made in the region; the example in figure three is on display at the British Museum, and is one of a collection of similar miniature canoes donated by a traveller named Fleetwood Sandeman, who purchased it in San Francisco in 1874 (Borlase 1878). The miniature canoe was made not long before Sandeman acquired it, and there is circumstantial evidence that it was once part of the private collection of Louis C. Sartori, a US naval officer in command of the Mare Island naval base at the time of the transfer of Alaska from Russia to the United States in $1867 .{ }^{1}$

The significance of this event is crucial to understanding this miniature. Native inhabitants of Alaska were pointedly excluded from the negotiations and the ceremony, reduced apparently to 'a few curious Indians' standing nearby (Jensen 1975, 101). These onlookers

\footnotetext{
${ }^{1}$ Another miniature canoe in the British Museum, Am1976,03.3, is so similar to this example that it is acknowledged as the work of the same hand. This second miniature was acquired by the Museum in 1976 from an American collector who had purchased in Philadelphia it from a sale of the effects of the Sartori estate. The miniature at that time still had one of Sartori's calling cards attached. Sartori was transferred from San Francisco to Philadelphia in 1873 at exactly the time the Sandeman collection was made available for sale.
} 
were of course anything but 'curious Indians'; they were prominent traders and powerbrokers witnessing their citizenship being traded between foreign capitals. They knew exactly what the event signified, and two years later Tlingit Chief Ebberts of Sitka held his own ceremony to mark the transfer of sovereignty, with a potlatch held in honour of the visiting former Secretary of State William Seward, the man who had arranged for the sale. This was Ebberts' chance to demonstrate his authority within a changing political situation over which he had had no control. He 'spread luxurious furs for [Seward] to walk on. A handsomely carved and painted chest covered with furs was his seat of honour, and Ebbits [sic] presented him with an ornamented hat, the furs and chest, and other gifts' (Garfield \& Forrest 1948, 55-56). This canoe may have been part of this gift; Sartori, as the local naval commander, is likely to have been present. Seward however was famously so rude to his hosts that he has still not been forgiven, and a totem pole publically insulting him still stands in Ketchikan.

In determining what this autoethnographic object actually depicts, it is worth comparing it to that collected by Malaspina. Again, this is a depiction of a head canoe, less sinuous but still significantly out of proportion with the dimensions of a sea-going vessel. Although the formline design has developed, appearing in more colours and characters than on the Malaspina miniature, the figure is once again a killer whale. Given the consistency, Sartori, or whomever was the owner of this miniature canoe, may have met and been presented with the canoe miniature by a direct descendant (politically, perhaps biologically) of the man with whom Malaspina exchanged goods.

What is most significant about this potential line of descent is that the head design of fullsized canoe had not been produced in the region since the very early nineteenth century: it is likely that no one alive had seen one made, maybe not even seen one on the water. Head canoes had been completely replaced by the mid-1820s by the Northern canoe, a more stable design capable of holding more cargo (Holm 1987). To the Tlingit carvers of the 1860s this is an obsolete canoe technology, analogous to makers of wooden sailing ship miniatures in late twentieth century Britain.

There is then no clear explanation as to why this would be an effective Native design for a miniature canoe in the late 1860s. To begin to understand this apparent anachronism requires engagement with the historical context of the region. Beyond the abrupt transference of sovereignty, about which the local chiefs were not consulted, there were other crises converging on the peoples of the Coast. Economic collapse caused by the regional extinction of the sea otter through over-hunting had led to a twenty year recession 
that eroded the authority of traditional chieftains, followed in 1862 by a small pox epidemic of unparalleled ferocity. The Tlingit peoples of Southern Alaska suffered 53\% mortality in just a year. The neighbouring Haida lost $72 \%$ of their population over the same period (Boyd 1999, 229). The effect of this disaster was profound; as described by a Haida elder: 'Smallpox running through our people can be likened to a fire burning a library of 30,000 books. Our elders are our books of knowledge' (Wilson 2009).

With so many dead, survivors left their villages and congregated into new towns. Into the empty villages came settlers, who clear cut ancient groves of cedar, essential for canoe construction. Missionaries and government officials followed, with new laws and religions and restrictions, and with them came collectors, sweeping depopulated villages and associated grave sites for objects they could crate up and sell to museums. This is where most of the collections found in European and American museums from the region ultimately originate (Cole 1985).

A chieftain in 1869, feeling his wealth and people under threat of non-Native dominion, sought a symbol which synecdochically presented himself and by extension his people, just as his ancestors did to Malaspina, as powerful chieftains of the killer whale. He achieved this using as the prototype not a physical canoe, but the memory of canoes that his wealthy, revered ancestors sailed. These objects are not, as museums have often portrayed them, representative depictions of canoes or canoe culture; they are instead ideological statements of ownership, identity and authority, which were deliberately distributed outside the community to specific non-Native peoples. .

Miniatures such as this are complex because their ideological communications are coded, reliant on local contextual understanding of their affordances in order to make an accurate translation, and thus it is difficult to read them accurately outside this environment. They were made to be read by specific people in specific contexts, but as they move beyond those contexts into the hands of curators new interpretations are imposed on them which overlook both their specific contexts and their elemental affordances, which nevertheless continue to operate, affecting their environment through the inherent fascination of the miniature dissonance they provoke. A century and a half after it was made, this miniature is still able to resonate with the grief and pride of its original maker, even if its current location obscures its full potential.

Figure four 
The final Northwest Coast example shifts forwards to a contemporary carver and away from the museum context, and helps to contextualise the historic examples as part of a cross-cultural, multi-generational process. Joe Gobin is a master carver of the Tulalip Tribes, a Salishan group who live on a reservation north of Seattle. He has carved numerous full-sized canoes and totem poles and is highly experienced, skilled and respected as a modern Northwest Coast artist. In 2009, he was commissioned to carve an object to present to American and Canadian government officials as part of the culmination of a campaign to rename of the waters off Washington State and Southern British Columbia from names based on early European explorers.

The campaign sought to eliminate the colonial names for the bodies of water on and around which the Salishan peoples live to become known collectively as 'The Salish Sea', both in Canada and the United States. To celebrate this outcome several prominent Salishan carvers were invited to create miniature canoes for presentation to government officials at a formal renaming ceremony at Songhees on Vancouver Island

In an interview given to the author, Gobin described his desire to make his a miniature canoe 'perfect'; to make something so that 'a hundred years from now someone can look at this and see what a [Tulalip] canoe looks like'. Carved by eye, rather than using direct measurements, it is still slightly disproportionate with an exaggerated bow and stern. It is not a proportional model in the European sense, nor an imaginative construct like the earlier Tlingit examples, but instead a mid-point; an effort to show unknowledgeable audiences what a canoe should look like while still bearing enough imagination to focus on appearance rather than strict accuracy.

Gobin understood that this miniature canoe would be presented to the American government as a diplomatic gift between the Tulalip and the United States; his exact words were that it was to be 'given to Obama', although he is likely to have been speaking figuratively. Unfortunately it appears that after its presentation at the ceremony, which Gobin did not attend, the canoe disappeared somewhere between the Canadian Department of Indigenous Affairs and the Office of the Governor of Washington State. Its eventual fate does not however render it a failure; once presented before the crowd and news media, whether this particular autoethnographic miniature made a successful journey is less important than the public acknowledgment that the journey was begun, that the miniature canoe was distributedas a representative of Gobin and his people. Gobin's canoe is no different to the work of the carvers in 1790 or 1870; using an imaginative contruct in the shape of a miniature canoe as a representative stand-in for the Tulalip and sending it 
out to unknowledgeable foreign audiences, with the expectation that people will look at it, become fascinated and ultimately have their opinions manipulated in the way the carver intended by the engagement. As with the other examples, it is inherently semiophoric.

\section{Lead barques of Ancient Egypt}

These examples demonstrate that the transmission of ideological information through essentially functionless objects; miniatures, is an embedded, common and implicitly understood practice among Northwest Coast artists to this day; one that is inherently authentic. Miniature canoes have consistently been produced as a means of communicating specific ideas to specific people as part of a developing colonial power relationship in the region and yet this ideological purpose becomes obscured when they enter museums and instead are used as representative depictions of canoe culture or Northwest Coast peoples. They are objects of great sophistication too often treated as simplistic and sometimes inauthentic expressions of souvenir art or facile inauthenticity, and yet due to miniature dissonance they have continued to communication within the museum contact zone, continuing to express ideological information which can be recognised by visiting descendants in just the manner described by Collison.

The final example presented here broadens consideration of miniatures beyond the confines of the post-contact Northwest Coast, illustrating not only temporal and geographic depth to the theory but also the dangers of over-simplistic seriation, convenient curatorial interpretation and the consequences of miniature dissonance in the archaeological record. To give an example of what can be lost when curators fail to acknowledge the unrealistic qualities of a miniature, I will finish by discussing a small group of objects from Ancient Egypt that featured in the Sunken Cities exhibition at the British Museum (May-Nov. 2016), as a comment on the type of interpretation under discussion, and a critique of the ways in which miniatures are sometimes presented.

In the exhibition there was a display case which features a series of small lead votive offerings shaped like Nile barges. They are, according to the catalogue, understood as depicting papyrus barques, and most had been thrown into the Grand Canal of ThonisHeraclion around the Temple of Amun-Gereb as part of the Osiris festival of the twenty- 
second Khoiak. Others were found deliberately buried under flagstones on the banks of the canal. (Goddio 2016, 182-183). These miniature barges have clearly created miniature dissonance in their position within the exhibition because although the commentary in the catalogue states that they are "identical to the [full-sized] barques", this is palpably not the case. They are made of lead, not papyrus, and are very simple, retaining little more than the barge shape and throne, sometimes with a steering oar and simple incised decoration which may be a skeumorphic nod to the papyrus construction of full-sized barges. They are not remotely reliable in proportion with one another, let alone in comparison with a full-sized barge.

The catalogue notes that 'even the choice of their manufacture may have been significant, as lead is the metal most often associated with Osiris'. Here, a miniature vessel made and distributed in a specific context is used as an icon of an entire class of Egyptian watercraft, with inferences about the design of papyrus boats taken from lead miniatures that bear only the broadest similarity with the prototype; it might be more valuable instead to consider the affordances within the context. These were votive offerings, made of sacred metal and cast into a sacred canal. They were therefore offerings made by the Egyptians of the fourth to the second Century B.C. directly to Osiris; consequently they were to be understood, to be shaken, not by a person, but by a god.

This then opens productive and intriguing lines of enquiry: we might start by enquiring which elements of the barges are specifically necessary to attract the attention of a god; the significance of the barge-shape in sacred lead, the provision of the skeuomorphic papyrus details and the mode of transmission directly into the waters of the canal, or to question why all this was necessary and to consider whether the effect is diluted if one merely threw a lead bar into the canal instead.

The exhibition does an excellent job describing the appearance and context of these miniature barges, but it does not acknowledge that these miniature barges are direct and illustrative evidence of human communication with a deity, and consequently human understanding of how that deity thinks. Egyptians did not make these to teach future generations of museum visitors about barge mechanics or ceremonies, they made them to speak to Osiris, and included only those affordances necessary to do so and omitted all else. In order for modern curators to consider these objects effectively, to 'shake' them as Osiris might and as the creators intended, it is necessary to do more than recognise that the objects are 'votive offerings', but to think precisely about what aspects of their creation and use make them effective in human-deity communications, and what makes them recognisable 
to Osiris as appeals to his munificence. In this they are just as important examples of Clifford's contact zone as the Northwest Coast examples; in some ways the absence of living near-relatives makes a full engagement with their dissonant appearance even more crucial to their presentation.

In each of the examples cited in this article, the objects have been created in a particular time and place for a particular communicative reason, and may have had no intended use beyond that purpose. Their subsequent collection by curators as icons of the objects they appear to depict and their use in the museum setting as synecdoches of entire peoples inevitably causes dissonance, clashes between the original intentions for the design and later curatorial efforts to make them speak in ways never originally intended. Because they express the genuine intentions of the creator they have authenticity, and because they have no practical function they can reveal the imaginative decision making process which created them, regardless of non-indigenous outside influence; in this way their original ideologies are never completely lost.

Curators have, over the last three centuries, created a system of object categorisation based on museum priorities and have fitted collected objects into this system as convenient for their purposes. This may be a necessary tool in order to manage collections, to present these collections to the wider world and provide insight into the peoples that they understand these collections to represent. Curators however should also acknowledge that this system can oversimplify the complexities of objects, particularly those of primarily representative function, and can sometimes lead to assumptions that disregard and disconnect the object, especially an authoethnographic, semiophoric object sometimes deemed 'inauthentic' by non-Native influence, from their the original, imaginative origins. In the case of miniatures, their particular affordances lead to 'miniature dissonance', where the miniature is inefficient at fulfilling the role intended for it by the museum curator because the original ideology cannot be constrained.

The result is dissonance, which leaves curators and visitors uncomfortable with these objects, failing to acknowledge the communicative technologies and ideologies they contain, which can reveal far more about the artists who made them and the societies from which they come than is often realised. In the context of miniatures within museum contact zones, this is a failure of engagement which emphasises pseudo-scientific seriation over original intentionality in a manner which disenfranchises the original creator and their descendants and prevents acknowledgment of the miniatures' original purposes. If museums are serious in their efforts to shift the power relations in the contact zone which 
they create from curator to source community, from function to engagement, then they must begin to look beyond their self-imposed categories and think of objects such as these presented here not as icons of their prototypes, but indexes of entire modes of communication. 
Funding for this research supplied by the Arts and Humanities Research Council. Support provided by the British Museum and University College London. The author wishes to thank Dr. Dora Thornton of the British Museum for her advice on the article.

Ames, Michael. 1992. Cannibal Tours and Glass Boxes: the Anthropology of Museums. Vancouver: UBC Press

Asad, Talal. 1991. 'From the History of Colonial Anthropology to the Anthropology of Western Hegemony' in Colonial Situations: Essays on the Contextualization of Ethnographic Knowledge, ed. George W. Stocking Jr., pp.314-324. History of Anthropology Series, Vol. 7. Madison: University of Wisconsin Press

Berezkin, Yuri. 2007. ТЛ ИНКИБІ: КАТАЛ ОГ КОЛ Л ЕКЦИЙ КУНСТКАМЕРБІ [The Tlingit People: Catalogue of the Kunstkamera Collections]. St. Petersburg: Kunstkamera

Boast, Robin. 2011. "Neocolonial Collaboration: Museum as Contact Zone Revisited” in Museum Anthropology, Vol. 34, Issue. 1, pp.56-70

Borlase, William Copeland. 1878. Sunways: A Record of Rambles in Many Lands. London: General Books

Boyd, Robert. 1999. The Coming of the Spirit of Pestilence: Introduced Infectious Diseases and Population Decline among Northwest Coast Indians, 1774-1874. Seattle: University of Washington Press

Brown, Michael F. 2009. "Exhibiting Indigenous Heritage in the Age of Cultural Property" in Whose Culture? The Promise of Museums and the Debate over Antiquities, ed. James Cuno, pp.145-164. Princeton \& Oxford: Princeton University Press

Clerici, Nadia. 2002. "Indian Voices in the European Context" in European Review of Native American Studies, Vol. 16, Issue. 2, pp.1-10

Clifford, James. 1999 [1997]. "Museums as Contact Zones" in Representing the Nation: A Reader, eds. David Boswell \& Jessica Evans. London \& New York: Routledge, pp. 435-457

Collison, Nika. 2016. “An Unbroken Line: Haida Art and Culture”. Lecture presented for the Canada Seminar, Lady Margaret Hall, University of Oxford. Text provided to author by speaker. 12 February 2016

Cole, Douglas. 1985. Captured Heritage: The Scramble for Northwest Coast Artifacts. Vancouver: Douglas \& MacIntyre

Davy, Jack. 2015. 'A LEGO Snowmobile and the Elements of Miniaturisation' in Anthropology Today, Vol. 31, No.6 (Dec, 2015)

Errington, Shelly. 1998. The Death of Authentic Primitive Art and Other Tales of Progress. Berkeley \& Los Angeles: University of California Press

Evans, Christopher. 2012. 'Small devices, memory and model architecture: Carrying knowledge' in Journal of Material Culture, Vol.17, No.4, pp.369-387

Foxhall, Lin. 2014. 'Introduction: miniaturization' in World Archaeology, Vol.47(1), pp.1-5

Garfield, Viola E. \& Linn A Forrest. 1948. The Wolf and the Raven. Seattle: University of Washington Press

Geismar, Haidy. 2013. Treasured Possessions: Indigenous Interventions into Cultural and Intellectual Property. Durham \& London: Duke University Press

Gell, Alfred. 1998. Art and Agency: An Anthropological Theory. Oxford University Press

Glass, Aaron (ed). 2010. Objects of Exchange: Social and Material Transformation on the Late Nineteenth-Century Northwest Coast. New York: Bard Graduate Center

Graburn, Nelson H. H. (ed.). 1976. Ethnic and Tourist Arts: Cultural Expressions from the Fourth World, Berkeley: University of California Press

Goddio, Franck (ed.). 2016. Sunken Cities: Egypt's Lost Worlds. London: Thames \& Hudson 
Harris, Christine. 1992 [1966]. Raven's Cry. Vancouver \& Toronto: Douglas \& MacIntyre

Holm, Bill. 1983. Box of Daylight: Northwest Coast Indian Art. Seattle \& London: University of Washington Press \& Seattle Art Museum

Holm, Bill. 1986. 'The Dancing Headdress Frontlet: Aesthetic Context on the Northwest Coast' in The Arts of the North American Indian: Native Traditions in Evolution, ed. Edwin L. Wade, pp.133-140. New York: Hudson Hills Press

Holm, Bill. 1987. "The Head Canoe" in Faces, Voices and Dreams: A Celebration of the Centennial of the Sheldon Jackson Museum. pp.143-156. Sitka: Sheldon Jackson Museum

Jacknis, Ira. 1985. 'Franz Boas and Exhibits: On the Limitations of the Museum Method of Anthropology' in Objects and Others: Essays on Museums and Material Culture, ed. George W. Stocking Jr., pp.75-111. History of Anthropology Series, Vol. 3. Madison: University of Wisconsin Press

Jensen, Ronald J. 1975. The Alaska Purchase and Russian-American Relations. Seattle: University of Washington Press

Jonaitis, A. 1991. 'Representations of Women in Native American Museum Exhibitions: A Kwakiutl Example' in European Review of Native American Studies, Vol. 5, Issue. 2, pp.29-32

Keene, Suzanne. 2005. Fragments of the World: Uses of Museum Collections. Oxford: Elsevier ButterworthHeinemann

King, J. C. H. 1986. 'Tradition in Native American Art' in The Arts of the North American Indian: Native Traditions in Evolution, ed. Edwin L. Wade, pp.65-92. New York: Hudson Hills Press

King, J. C. H. 2012. 'Art, Ambiguity and the Haida Collection at the British Museum' in American Indian Art Magazine, Vol.38, No.1

Knappett, Carl. 2012 'Meaning in Miniature: Semiotic Networks in Material Culture' in Excavating the Mind: Cross Sections through Culture, Cognition and Materiality, eds. M. Jensen, et al., pp.87-109. Aarhus: Aarhus University Press

Krmpotich, Cara \& Laura Peers. 2013. This is Our Life: Haida Material Heritage and Changing Museum Practice. Vancouver: University of British Colombia Press

Lenz, Mary Jane. 2004. 'No Tourist Material: George Heye and his Golden Rule' in American Indian Art Magazine, Vol.29, No. 4

Lévi-Strauss, Claude. 1966 [1962]. The Savage Mind. University of Chicago Press

Lévi-Strauss, Claude. 1985. 'Introductory Address' in Art as a Means of Communication in Pre-Literate Societies, ed. Dan Eban, pp.1-6. Jerusalem: The Israel Museum

Lyons, Claire. 2002. 'Objects and Identities: Claiming and Reclaiming the Past' in, Claiming the Stones, Naming the Bones. Cultural Property and the Negotiation of National and Ethnic Identity eds. Elazar Barkan \& Ronald Bush, pp 116-132. Los Angeles: Getty Publications.

Mack, John. 2007. The Art of Small Things. London: British Museum Press

Myers, Fred. 2006. 'Primitivism', Anthropology, and the Category of 'Primitive Art'" in Handbook of Material Culture, ed. Christopher Tilley, Webb Keane, Susanne Küchler, Michael Rowlands \& Patricia Spyer, pp.267-284. London: SAGE Publications

Pearce, Susan M. 1992. Museums Objects and Collections: A Cultural Study. Leicester University Press

Peers, Laura \& Alison K. Brown (eds.). 2003. Museums and Source Communities: A Routledge Reader. London \& New York: Routledge

Phillips, Ruth B. 1995. "Why not Tourist Art? Significant Silences in Native American Museum Representations" in After Colonialism: Imperial Histories and Postcolonial Displacements, ed. Gyan Prakash, pp.98-128. Princeton University Press 
Phillips, Ruth B. 1998. Trading Identities: The Souvenir in Native North American Art from the Northeast, 17001900. Seattle: University of Washington.

Pinney, Christopher. 2005. 'Things Happen: Or, From Which Moment Does That Object Come?' in Materiality ed. Daniel Miller, pp.256-272. Durham \& London: Duke University Press

Pomian, Krzysztof (trans. Elizabeth Wiles-Portier). 1990 [1987]. Collectors and Curiosities: Paris and Venice, 1500-1800. Cambridge: Polity Press

Porsild, Morten P. 1915. 'Studies on the Material Culture of the Eskimo in West Greenland' in Meddelelser on Gronland, Bind LI, No.7

Poulter, Emma. 2011. 'The Real Thing? Souvenir objects in the West African Collection at the Manchester Museum' in Journal of Material Culture, Vol.16, No.3, pp.265-284

Pratt, Mary Louise. 1991. "Arts of the Contact Zone” in Profession, pp. 33-40

Ramsey, Heather \& Kwiaahwah Jones (ed). 2010. Gina 'Waadluxan Tluu: The Everything Canoe. Skidegate: Haida Gwaii Museum Press

Renker, Ann M. \& Erna Gunther. 1990. 'Makah' in Handbook of North American Indians, Vol. 7, Northwest Coast, ed. Wayne Suttles, pp.422-430. Washington DC: Smithsonian Institution

Ryle, Terence. 2017. 'Tribal material is seen as modern art' in Antiques Trade Gazette, Issue 2285, 1 April 2017, pp.16-17

Sola, Tomislav. 1997. 'Museums, Museology, and Ethics: A Changing Paradigm' in Museum Ethics, ed. Gary Edson, pp.168-175. London: Routledge

Wilson, Barb. 2009. 'Sometimes, it's all right there' in Haida Laas: Journal of the Haida Nation. March 2009, p.6

Zilberstein, Anya. 2007. 'Objects of Distant Exchange: The Northwest Coast, Early America, and the Global Imagination' in The William and Mary Quarterly, Vol.64, No.3, pp.591-620 